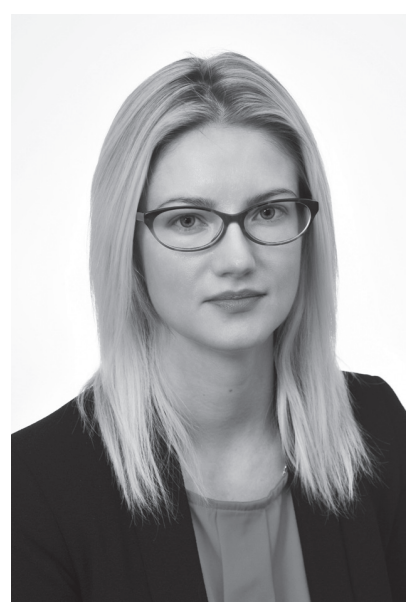

\section{Sigita Astikienè}

Vytauto Didžiojo universitetas
Sigita Astikienè - Vytauto Didžiojo universiteto etnologijos ir folkloristikos magistrè.

Adresas: Jaunimo g. 7-13, LT-20155 Ukmergè.

Tel. $+370 \sim 67049188$.

El.paštas: sigita.astikiene@gmail.com.

Sigita Astikienè:- MA in Ethnology and Folkloristics, Vytautas Magnus University.

Address: Jaunimo str. 7-13, LT-20155 Ukmergè.

Phone: $+370 \sim 67049188$.

E-mail: sigita.astikiene@gmail.com.

\title{
„ČIA NE DARBAS, O SVAJONĖ...": BIBLIOTEKININKŲ GYVENIMO PASAKOJIMŲ YPATUMAI
}

\section{Anotacija}

Straipsnyje analizuojami ir lyginami 2016-2018 m. Ukmergès rajone užrašyti buvusių ir šiandien dirbančių bibliotekininkų gyvenimo pasakojimai. Nagrinëjamuose naratyvuose ryškiausiai atsiskleidžia bibliotekininko tapatybès bei profesinès veiklos sąsajos, atsispindi kultūrinio ir socialinio visuomenès gyvenimo realijos. Lyginant buvusių ir esamų bibliotekininkų pasakojimus galima matyti skirtingų kartų vienos profesijos atstovų patirti ir suprasti, kaip žmogaus asmenybės ir profesijos ypatybès atsiskleidžia konkrečiu istoriniu laikotarpiu. Bibliotekininkų naratyvuose iškyla bendruomenès svarba priimant ị savo tarpą ir palaikant kultūros darbuotoją, ryškejja bibliotekos kaip atstumtųiu visuomenès grupių „prieglobsčio“ vieta, papildomi bibliotekininko visuomeniniai vaidmenys.

PAGRINDINIAI ŽODŽIAI: gyvenimo istorijos, asmeninès patirties pasakojimai, bibliotekininkai, biblioteka.

\begin{abstract}
This article analyses and compares life narratives from the previous and currently working librarians of Ukmerge district between the time period of 2016-2018. The analysed narratives reveal the most distinct connections between identity of librarians and their professional activity, and reflect the realia of cultural and social life. Comparison of previous and current narratives reveals experiences of different generations having the same profession, what helps to understand how the specific features of human personality reveal in a specific
\end{abstract}


time period. The narratives of librarians reveal the importance of the community when accepting a cultural worker to a team and supporting him/her, also the role of a library as a "shelter" for the community groups that are considered outcasts becomes apparent, and the supplementary social roles of a librarian are revealed.

KEY WORDS: life narratives, narratives of personal experience, librarians, library.

doi:http://dx.doi.org/10.15181/rh.v23i0.1794

I va d a s

Straipsnio objektas - su profesija susiję bibliotekininkų gyvenimo pasakojimai, užrašyti Ukmergès rajone. Darbe iškeltas tikslas - išanalizuoti užrašytus bibliotekininkų pasakojimus ir atskleisti šių pasakojimų specifiką bei turinio ypatybes. Medžiaga tyrimui rinkta 2016-2018 m., iššifruoti pasakojimai sudaro 162 puslapius. Tyrimo metu iš viso surinkta trisdešimties bibliotekininkų (1 vyro ir 29 moterų) pasakojimai. Iš viso apklausta 14 buvusių ir 16 šiuo metu dirbančių, 32-91 metų amžiaus, Ukmergès miesto arba rajono bibliotekininkų. Straipsnyje pateikejai cituojami nuasmeninus jų duomenis, nurodant tik vardus. Tyrimo medžiaga saugoma Vytauto Didžiojo universiteto Kultūrų studijų katedroje esančioje Etnologijos rankraštyno byloje Nr. 2663 (toliau VDU ER 2663). Renkant medžiagą naudotasi pusiau struktūruoto interviu ir stebejjimo metodais. Analizuojant surinktą medžiagą taikyti aprašomasis, lyginamasis turinio bei interpretacinis metodai. Straipsnis parengtas pagal 2018 m. apgintą magistro darbą, kurio vadovè yra prof. Gražina Kazlauskienè.

Asmeninès patirties pasakojimai - įvairios istorijos iš žmonių gyvenimo, jų praeities prisiminimai. Sparčiai nykstant ir menkejjant klasikinei tautosakai, ne vien daugelyje Vakarų šalių, bet ir pas mus folkloristai gręžiasi i kitokio tipo tekstus. Asmeninès patirties pasakojimai (personal experience stories) - įvairiopo pobūdžio istorijos, sakytume, „iš gyvenimo“, žmogaus dèl tam tikrų priežasčiu prisimenamos ir pasitaikius progai pasakojamos kitiems (Būgienè 2008). Vieni iš tokių asmeninès patirties pasakojimų gali būti pasakojimai apie savo profesinę veiklą. Užrašius žmonių pasakojimus apie jų darbinę veiklą, galima įžvelgti nemažai bendrų konkrečiam laikotarpiui būdingų detalių. Istorikai dažnai vartoja ir žodinès istorijos terminą. Judith Moyer teigia, kad sistemingai užrašius tokias žodines istorijas, galima iš jų sudèlioti bendrą tiriamo reiškinio vaizdą ir pamatyti ji istoriniame kontekste (Moyer 1993). 
Lietuvoje vienos profesijos žmonių pasakojimai folkloristų dar nėra tyrinèti, o bibliotekininkų bendruomenè Lietuvoje gana didelè ir bibliotekos reikšmė visame Lietuvos kultūriniame gyvenime buvo ir yra nemaža. Atlikus tokių pasakojimų analizę galima rasti nemažai bendrų visiems naratyvams būdingų vietų, pagal kurias išryškeja kultūrinio, socialinio ir istorinio Lietuvos gyvenimo aspektai. Nuo XX a. pradžios profesijos pasirinkimas ir darbas tampa vis svarbesni aspektai žmonių gyvenime, todèl aktualu panagrinèti, kaip pasakojimuose apie darbo metus atsiskleidžia žmogaus tapatybè.

Darbų, kuriuose lietuvių folkloristai nagrinėtų asmeninės patirties pasakojimus apie žmonių profesinę veiklą, nėra paskelbta, tačiau apie asmeninius pasakojimus kitomis temomis yra rašęs ne vienas folkloristas. Lina Būgienė rašè apie moterų autobiografinius gyvenimų pasakojimus, nagrinejjo, kas jiems būdinga, kuo skiriasi jų stilius ir struktūra, kokie bruožai atsiskleidžia vyrų ir moterų pasakojimuose, kaip gyvenimo istorijose atsispindi konkretaus krašto istoriniai ịvykiai (Būgienẻ 2011, 2012). Autobiografiniu pasakojimų grupes - gyvenimo istorijas ir asmeninès religinès patirties pasakojimus - nagrinèjo ir Rasa Račiūnaitė-Paužuolienė (Račiūnaitė-Paužuolienè 2011). 2017 m. leidinyje „Tarp knygu“ publikuotas šio darbo autorès straipsnis „Bibliotekininkų pasakojimuose - praeities gyvenimo atspindžiai“, kuriame pateikiami ir analizuojami buvusių Ukmergès rajono bibliotekininkų prisiminimai (Astikienè 2017).

Vilma Daugirdaitė tyrinèjo, kaip tautosakos pateikejuc gyvenimo pasakojimuose reiškiasi folklorinė patirtis, aptarẻ folkloro žanrų įtaką tokio tipo pasakojimams (Daugirdaitė 2006). Bronė Stundžienė pabrèžè asmeninių pasakojimų svarbą folkloristikoje kaip visos tautos atminties išsaugojimo tąsą (Stundžienė 2012). Asmeninès patirties naratyvus analizuoja ir sociologai bei istorikai. Sigita Kraniauskienè nagrinejo bendrosios identiteto sąvokos sampratą ir jos sąsajas su autobiografiniu pasakojimu, apibrèžè kolektyvinio ir individualiojo identiteto sąvokas (Kraniauskienė 2004). Taip pat minètinas ir istorikès Dalios Marcinkevičienès darbas „Prijaukintos kasdienybès: 1945-1970 metai. Biografiniai Lietuvos moteru interviu“, kuriame autorè, nagrinėdama moterų pasakojimus, apžvelgia, kaip moterų tapatybès atsiskleidè okupuotoje Lietuvoje, kokią įtaką joms turejjo sovietinè ideologija, šiek tiek dèmesio skirdama ir profesinei moteru veiklai (Marcinkevičienė 2007). 
Iš užsienio mokslininkų, analizavusių pasakojimus, minètina suomių folkloristė Annikki Kaivola-Bregenhøj, kuri aptarė pasakojimo žanrus, eigą, pasakotoją, išskyrẻ bendruosius bruožus, pagal kuriuos galima atpažinti tautosakinès prozos pateikejus (Kaivola-Bregenhøj 2005). Asmeninès patirties pasakojimus taip pat nagrinejjo ir Adedamola Akinsanya bei Christianas Bachas. Mokslininkai rašo apie tai, kad asmeninès patirties pasakojimai yra itin efektyvus būdas sužinoti norimą informaciją ir pagal ją sukurti bet kurios akademinès srities pagerinimo modeli (Akinsanya, Bach 2014). Užsienio tyrèjai yra dèmesio skyrę ir tam tikroms profesijoms atstovaujančiu asmenų pasakojimams, daugiausia - mokytojų naratyvams. Profesinès veiklos ir asmens tapatumo santykị nagrinejjo Christopheris Day (Day 2006), apie asmeninio ir situacinio konteksto ypatybes, susijusias su žmogaus profesine veikla, rašè ir Mary Beattie (Beattie 2000).

Straipsnyje apžvelgiami buvusių ir šiandien dirbančių bibliotekininku prisiminimai apie skaitymą ir biblioteką vaikysteje ir jaunysteje, darbo pradžią bei bibliotekininko darbo specifiką. Šiuose naratyvuose ryškiausiai atsiskleidžia bibliotekininko tapatybès bei profesinès veiklos sąsajos, atsispindi kultūrinio ir socialinio visuomenès gyvenimo realijos. Lyginant buvusių ir esamų bibliotekininkų pasakojimus galima matyti skirtingų kartų vienos profesijos atstovų patirtį ir suprasti, kaip žmogaus asmenybès ir profesijos ypatybės atsiskleidžia konkrečiu istoriniu laikotarpiu.

Skaitymas ir biblioteka vaikystès bei jaunystés prisiminimuose

Visi užrašyti pasakojimai yra buvusių ir dabartiniu bibliotekininkų, kurių gyvenimo sąlygos buvo skirtingos. Vyresnieji bibliotekininkai daugiau pasakojo apie pokario ir sovietmečio laikus, o dauguma šiandien dirbančiųjų - apie nepriklausomybès laikotarpị.

Iš pasakojimų galima matyti, kad visi bibliotekininkai noriai prisimena savo vaikystès bei jaunystės biblioteką, pasakoja apie pomėgị skaityti. Greičiausiai dẻl sunkių gyvenimo sąlygų bei menko išsilavinimo iš buvusių bibliotekininkų pasakojimų matomas neigiamas dalies žmonių požiūris į knygas ir skaitymą. Ne vieną pateikeją tévai bardavo dèl per didelio domejjimosi knygomis, laike tai nereikalingu pomégiu, dèl to ne viena bibliotekininkè prisipažino, kad norint paskaityti tekdavo nuo tẻvų slèptis. Anot etnologès Auksuolès Čepaitienès, kaime vaikai kartu su suau- 
gusiaisiais dirbo jiems priskirtus ūkio darbus, visi žinojo savo pareigas ir užduotis (Čepaitienè 2013). Vaikai buvo auklëjami per darbą, manoma, kad dirbdami taps darbštūs, tvarkingi, ịgis ir praktinių ịnūdžių, reikalingų pradejjus savarankišką gyvenimą (Vyšniauskaitė 2008). Kad iš tiesų XX a. pirmosios pusės Lietuvos kaime visi šeimos nariai, tarp jų - ir mažiausieji, turèjo savo darbus, atskleidžia pateikejjos Monikos atsakymas ị klausimą, ar tèvai arba seneliai skaitydavę vaikystėje: „Nebuvo kada... Nebuvo kada. Tais laikais labai... Kaimo žmogus yra labai užimtas. Dar mokyklon nejjom, mum jau buvo darbas prižoliauti. $<\ldots>$ Kiekvienam darbas buvo paskirstytas. Buvo pokaris, buvo sunku...“ (VDU ER 2663/9, 51).

Dauguma pasakotojų mini ir savo vaikystės biblioteką, kurią prisimena teigiamai, iš naratyvų matyti, kad pateikèjos vaikystejje gerbẻ ir mylëjo savo bibliotekininkes. Tokie gražūs vaiko ir bibliotekininkès santykiai atsiskleidžia pateikejos Valerijos pasakojime: „Aš kilus iš Užugirio, ten mano vaikystė, ten Lèno biblioteka buvo, per ežerą reikèdavo eit, aplink toli buvo, 3-4 km aplink ežerą reikèdavo eit, o ežeras kai užšąla - ten skyré ežeras mūsų kaimą ir biblioteką, tai eidavom tiesiai per ežerą í biblioteką. Imdavau knygas iš ten ir greit perskaitydavau. $<\ldots>$ Man labai patiko eiti ì tą biblioteką. Su bibliotekininke mes kaip draugès beveik buvom, jauna buvo, aš tuo metu buvau dar vaikas, nu paauglè, ne tai vaikas, bet paauglè “ (VDU ER 2663/10, 56).

Kaip teigia sociologė S. Kraniauskienè, vyresnio amžiaus žmonių gyvenimo istorijos turi nemažai mito elementų - kuriama savotiška priešistore (Kraniauskienė 2002). Šiuo atveju priešistore būtų galima laikyti daugumos pateikèjų artimiausių žmonių neigiamą požiūrị i knygas ir skaitymą, kuris pateikèjų vaikystèje vis dèlto nesuformavo neigiamo požiūrio ị knygą. Kaip priešpriešą tam galima iškelti teigiamus pateikejjų santykius su jų vaikystės biblioteka ir bibliotekininku, kas galejjo nulemti rinktis būtent bibliotekininko kelią.

Šiuo metu dirbančios bibliotekininkès vaikysteje taip pat skaitė, eidavo ị biblioteką ir daugumai tai turejjo ịtakos vèliau renkantis profesiją. Pažymètina tai, kad šiandienos bibliotekininkų pasakojimuose apie vaikystę nèra naratyvų, kuriuose matytųsi, kad tèvai būtų draudę skaityti knygas, kad reikèję nuo tėvų slëptis. Esamų bibliotekininkų pasakojimuose apie vaikystę atsiranda ir naujų motyvų, kokių nebūta jau pensininkais tapusių bibliotekininkų pasakojimuose - pirmiausia, tai prisiminimai apie namų 
bibliotekèlę. Taip pat dabartiniai bibliotekininkai daug daugiau pasakojo ir apie tai, kad knygas jiems skaitydavo tèvai arba seneliai. Tai galima sieti su tuo, kad vèlesniais laikais, apytiksliai po 1950 m., keitèsi žmoniu požiūris ị išsilavinimą, susidarẻ sąlygos įsigyti knygų, jas žmonès pirkdavo, turẻdavo vis daugiau asmeninių bibliotekèlių, taigi daugiau ir vaikams skaitydavo. Vyresniųjų bibliotekininkų, gimusių 1927-1950 m., tèvai skaitydavo retai arba išvis neskaitydavo, nes dauguma buvo arba beraščiai, arba baigę tik keletą mokyklos klasių. Tačiau ne viena pateikejja pabrèžè, kad, nors ir paskendę darbuose, atrasdavo laiko vaikams pasekti pasakų.

Dar vienas naujas šiandienos bibliotekininkų prisiminimų apie vaikystę motyvas - siužetiniuose žaidimuose, ypač mėgtuose mergaičių, imituoti bibliotekos darbą. Pateikèja Genẻ pasakojo: „Nežinau dèl ko, bet aš labai žaisdavau biblioteką. Vietoj lẻlių, atsimenu, buvo tokia sena etažerè, už namo buvau ją pasistačius. Turejjau vaikiškų knygučių ir nemažai, gal nuo sesių likę, gal tiesiog pirkdavo, net nesigilinau, iš kur aš jas gaudavau. Tik, atsimenu, prikarpydavau popieriukų ir rašydavau, draugèm išduodavau knygas. $\mathrm{O}$ iš kur aš supratau, kad taip...< <..> žaisdavau pradinukè, kažkaip suprasdavau, kad aš galiu duoti knygas, jas užrašyti ir pasiimti paskui. Tai čia mano gal buvo genuose“ (VDU ER 2663/21, 109). Kaip pažymėjo edukologė Irena Stonkuvienè, tokie vaidmeniniai žaidimai itin reikšmingi socializacijos ir inkultūracijos procesams, nes vaikai žaidimo forma paprastai atkuria suaugusiųjų žmonių tarpusavio santykius bei darbinę veiklą. Tokiais žaidimais vaikai išreiškia norą patekti ị suaugusiųjų pasaulį, kuris kol kas jiems yra nepasiekiamas (Stonkuvienè 2013, 183).

Nagrinejjant pateikẻjų pasakojimus apie jų vaikystės biblioteką, galima įžvelgti skirtingą pasakojimų specifiką: vieni pateikejjai savo pasakojimą konstruoja per emocinę, psichologinę būseną, kurią jiems sukeldavo buvimas bibliotekoje, o kiti pateikẻjai daugiau kalba apie prisimenamus pačios bibliotekos erdvės vaizdus. Pateikejai, pasakodami apie vaikystės biblioteką, vartoja apibūdinimus, kuriais praeitis tarsi idealizuojama, sureikšminama - ,jausdavausi tarsi kitame pasaulyje“, „,knygos kaip relikvija“, „biblioteka kaip šventovè“. Kaip teigia etnologè R. Repšienè, ,,mitologizuodami praeitị ir istoriją, tampame savo pačių ieškojimų ir atradimų moralès ịkaitais, kad pasitelkę idealaus žaidimo strategiją performuotume savo kasdienybę kaip intenciją amžinybės link“ (Repšienė 2009, 30). Kadangi vaikys- 
tė paprastai yra mitologizuojama kaip geriausias, laimingiausias žmogaus gyvenimo tarpsnis, greičiausiai dèl to pateikejjai ją taip ir apibūdina.

Ir vyresnès, ir jaunesnès pateikejos pasakoja apie savo pirmąją bibliotekininkę, nuo kurios savybių ir elgesio priklausè, kaip noriai vaikai èjo į biblioteką. Tai parodo, kad biblioteka yra ne tik ta vieta, kurioje pasiimamos ir grąžinamos knygos, bet ir erdve, kur daug ittakos turi emocijos ir jausmai. Pažymėtina tai, kad vyresniosios pateikèjos apie savo vaikystès bibliotekininkę kalbèjo tik teigiamai, o antrosios grupès, jaunesniu pateikejjų, pasakojimuose atsiskleidžia, kad sutikta bibliotekos darbuotoja buvusi ir pikta, ir nemaloni. Matyt, tai galima sieti su tarybinès santvarkos bruožu, kai nebuvo labai stengiamasi įtikti vaikui, biblioteka apskritai buvo daugiau knygų saugykla, informacijos pateikimo vieta, o ne atvira, patraukli, bendrauti skirta erdvè.

Darbo bibliotekoje pradžia

Darbo pradžia daugumai žmonių paprastai yra nelengvas laikotarpis, o ypač sudètingas tarpsnis tai buvo vyresniųjų bibliotekininkų gyvenime. Dauguma jų yra gimę tarpukario arba pokario metais, dèl to vaikystejje teko susidurti su įvairiais dvasiniais ir materialiniais sunkumais. Dèl šių priežasčių dauguma pateikejjų ir dirbti ejjo praktiškai iš mokyklos suolo. Bibliotekininkẻ Julijona pasakojo apie ankstyvą darbo pradžią: „Aš atėjau dirbti šešiolikos metų. Reikejjo dirbti, tiesiog sąlygos vertè. Sąlygos vertẻ ir išèjau dirbt, pasiūlè... < ..> Aš augau labai vargingai, be tèvo, ir mama, ir dar sesuo buvo, bet sesuo žuvo avarijoj ir aš likau viena. Ir man reikejjo eit dirbt“ (VDU ER 2663/5, 32).

Vaikystejje patirtos artimųjų mirtys, karo ir pokario metų baisumai per anksti atèmé iš pateikèjų vaikystę, atvedè juos i̊ suaugusiųju gyvenimą. Tokie pateikejjų pasakymai: ,,sąygos verte ir išejau dirbt“, „beveik iš mokyklos suolo“, „vis tiek duonos kąsnio reikia“, ,,daugiau mokytis negalejau“, parodo, kad žmonės negalèjo nieko spręsti, teko tiesiog plaukti pasroviui stengiantis išgyventi. Šių išgyvenimų pateikejjai beveik neanalizuoja, juos pateikia tarsi įvadą i d darbo pradžią, tačiau iš kalbos ir emociju aiškiai matyti, kad žmonėms sunku pasakoti nors ir apie senus, bet ypač skaudžius ju gyvenimo įvykius. 
Esamų bibliotekininkų naratyvuose mažiau nusiskundimo sunkiomis gyvenimo aplinkybėmis, lèmusiomis būtinybę anksti eiti dirbti. Dauguma moterų dirbti pradejjo jau būdamos šiek tiek vyresnio amžiaus arba baigusios mokslus. Darbo pradžia bibliotekininkèms pasirodžiusi sunki dažniausiai dèl to, kad buvo sunku perprasti knygų išdèliojimo bibliotekoje sistemą, moterys jautẻ baimę apsijuokti prieš lankytojus, nerandant knygų, buvo nedrąsu bendraujant su nepažizstamais žmonėmis. Tokie negatyvūs išgyvenimai daugiau plaukia iš pačių jaunų darbuotojų psichologinio nusiteikimo, o ne dẻl priekabaus valdžiai atstovaujančių asmenų elgesio su jaunu darbuotoju ar nepalankaus kaimo bendruomenès požiūrio į bibliotekininką, kas matyti vyresniosios kartos prisiminimuose. Vis dèlto ne viena šiandien dirbanti bibliotekininkè išryškino ir bibliotekos kaip svajoniu darbo vietą - nors pradžia nebuvo lengva, pats darbas daugumai moterų buvo itin artimas širdžiai.

Šiandienos bibliotekininkių pasakojimuose apie darbo pradžią daugiau atsiskleidžia artumo ir bendravimo poreikis. Tai ypač matyti pasakotojų, kurių darbo pradžia buvo kaime, naratyvuose: „, $<>>$ Ten nelabai ką pažinojau, nei kur eit, nei ką prašyt, $\langle\ldots\rangle$ tai ta felčerè mane, kaip jauną žmogų, kažkaip labai paglobojo. $<\ldots>$ buvo labai gera praktika susipažinti su pačiais gyventojais, su pačia aplinka to krašto“. Tokie pasakymai parodo, kad atejusiam į kaimo biblioteką naujam darbuotojui labai svarbu rasti užtarimą, draugystę, pritapti naujoje vietoje. Buvusių bibliotekininkų pasakojimuose tokio ryšio ieškojimo matyti mažiau, jie daugiau susitelkę i save arba į skaitytoją. Taip pat artumo su skaitytoju paieškų mažiau galima pastebėti bibliotekininkų, kurie dirbo mieste, pasakojimuose. Anot Irenos Leliūgienės ir Justino Sadausko, šiandien miestuose itin ryškus prarastos bendruomenės aspektas - socialiniai santykiai dažnai beasmeniai, trumpalaikiai ir išskaidyti, todèl neturintys tarpusavio priklausomybès (Leliūgienè, Sadauskas 2011). Greičiausiai dèl šių priežasčiu ir atsiranda miesto ir kaimo bibliotekininkų ir skaitytojų bendravimo skirtumai.

Pasakojimuose apie darbo pradžią itin ryškūs emociniai išgyvenimai, susiję su asmeniniu pateikẻjų patyrimu. Kaip teigia L. Būgienė, ,,moterys dažniausiai šnekesnès, atviresnès, nevengiančios atskleisti net intymiausių smulkmenų ir nelaikančios gėdingu dalyku interviu metu apsipilti ašaromis $\langle\ldots\rangle$. Sunku net paaiškinti, iš kur ir kaip randasi toks sukrečiantis kalbintų moterų atvirumas ir kokios jo priežastys. Galbūt jis irgi kyla iš 
moteru tarpusavio santykių tradicinèje kaimo bendruomenejje, o folkloristès - minètais atvejais jaunesnès moterys, irgi pusiau sąmoningai priimamos kaip tos bendruomenès narès ir, dalijantis gyvenimo patirtimi, savotiškai „inicijuojamos“ t. y. parengiamos gyvenimui?"“ (Būgienė 2012, 92). Šiuo atveju atvirumas bei jautrių savo gyvenimo detalių atskleidimas pašnekovui galètų būti siejamas su priklausymu tai pačiai bibliotekininkų bendruomenei. Kadangi užrašinètoja, palyginti su pateikejomis, jauno amžiaus ir dirbanti bibliotekoje, pateikèjos galbūt jaučia artimą globejišką ryšs ir nevengia atsiverti.

\section{Darbas su skaitytojais}

Bibliotekos visais savo gyvavimo laikotarpiais siekė pritraukti skaitytojus, juos sudominti savo veikla ir paslaugomis. Pasakojimuose apie skaitytojus vaikus aiškiai galima įžvelgti per kelis dešimtmečius pasikeitusias vaikų skaitymo tradicijas. Ne tik Lietuvoje, bet ir kitose pasaulio šalyse atlikti tyrimai patvirtina sumažejusį vaikų ir jaunimo domėjimąsi knygomis, intensyvus ir pastovus skaitymas šiandien būdingas jau nedaugeliui (Varnienè-Janssen, Račkauskaitė 2015). Tai atsiskleidžia ir bibliotekininkų pasakojimuose. Buvę bibliotekininkai pasakojo apie noriai skaitančius vaikus, o esami - atvirkščiai, kalbejo, kad vaikai skaityti nebenori.

Šiandien, reaguojant i pasikeitusias skaitymo tendencijas, nuolat rengiami ir įvairūs skaitymo skatinimo projektai, skiriama lèšu skaitymui skatinti bei kalbos gebejimams formuoti. $\mathrm{O}$ viena pagrindinių institucijų, kurioje ugdomi šie vaikų igūdžiai, yra viešoji biblioteka (Petružienė, Gabalytė 2011). Šiuolaikiniai vaikai įnoringi, turintys specifinių poreikių, todèl naratyvuose ypač išryškejjo tai, kad bibliotekininkui privalu būti kūrybingam ir išmanyti šiuolaikines technologijas.

Viešoji biblioteka - atvira erdvė visiems visuomenès nariams, taip pat ir ịvairioms socialinès atskirties grupėms. İvairiais marginalų bruožais pasižyminčių asmenų, kurie paprastai visuomenejje sunkiai randa vietą, laikomi atstumtaisiais, yra gana daug. Kaip pažymėjo Gražina Maniukaitė, šių žmonių ,atskirtị dažniausiai lemia tai, kad niekam nerūpi jų vertybinès nuostatos, nėra galimybės išsakyti susikaupusias mintis, tiesiog būti išklausytiems. Jie tiesiog kitokie, daugumos traktuojami kaip keistuoliai, baltos varnos, atpirkimo ožiai“ (Maniukaitė 2007). Ne viena esama biblioteki- 
ninkè ir pasakojo būtent apie tokius žmones: asocialius, kenčiančius nuo alkoholizmo, apsileidusius, tačiau būtinai pabrèždavo, kad šie žmonès myli ir vertina knygą, ateina pabendrauti. Bibliotekininkès pasakojo ir apie dar vieną žmonių grupę - senyvo amžiaus vienišus asmenis, kurie pagal savo užimamas pareigas ar statusą seniau buvę gerbiami visuomenès nariai, o šiandien jie - taip pat tarp atstumtųių.

Tiesiog apie keistus, nepritampančius prie laiko sąlygų ir prie kitu žmoniu skaitytojus pasakojo pateikejja Genè: , $<\ldots>$ nebeatsimenu net vardo, pavardès to žmogaus, vadinau-Miškinis. Ateidavo iš kitapus upés, tai žiema - per ledą. O vasara, kadangi tilto nebuvo, tai jis valtele perplaukdavo. Labai ịdomus pašnekovas, labai apsiskaitęs, bet ateidavo toks apžèlęs barzda, bet švarus, nes visus drabužius plaudavosi upeje, maudydavosi upejje žiemq vasara, o gyveno žeminëje. Ir skaitydavo labai daug, ir skaitydavo prie žvakès. Tai kiek pats nusipirkdavo, kiek po renginio kokio lieka žvakiu ar ten kokiu žvakigaliu, surinkdavome jam ir jis nešdavosi“ (VDU ER 2663/21, 114).

Tokia šiu grupių socialinė atskirtis labai susijusi ir su jų gyvenimo kokybe, kuri įvairių mokslininkų dažnai siejama su materialine gerove, išsilavinimu, saugia gyvenimo aplinka ir kt. Vis dèlto tokie žmonès randa ir kitų išteklių patenkinti savo poreikius ir gyventi jiems priimtiną gyvenimą (Tereškinas 2014). Ir vienas iš tokių būdų yra lankymasis bibliotekoje, kur galima atrasti saugią socialinę erdvę - pabendrauti, pasiskolinti knygų, dalyvauti iqvairiuose renginiuose. I akis krinta tai, kad visų bibliotekininkiu pasakojimai apie šiuos žmones - šilti, be jokios paniekos ar nepagarbos, o tai parodo, kad ir pačios bibliotekininkès nèra abejingos visuomenès atstumtiesiems, gerbia kitokius žmones, priima juos tokius, kokie jie yra, ir ižvelgia juose gerų savybių ir privalumų.

Ir vyresniems, ir jaunesniems bibliotekininkams kartais tekdavo dirbti ir kitokius darbus. Be tiesioginio darbo, buvusiems bibliotekininkams nuolat buvo skiriama papildomų darbų, dažniausiai visai nesusijusių su kultūrine veikla. Pasakodami apie papildomus darbus vyresnieji bibliotekininkai vardijo gyvuliu ar pasẻlių surašymus, politinès literatūros reklamą, darbą rinkimų metu, pinigines rinkliavas. Dažniausiai šie darbai kultūros darbuotojams nebuvo malonūs, tačiau juos teko dirbti. Ne viename naratyve matyti, kad bibliotekininkas arba, plačiąja prasme, kultūros darbuotojas buvo nevertinamas, išnaudojamas, jam primetama kokia tik imanoma papildoma veikla. Be abejo, kad ir kaip bibliotekininkai nenoré- 
jo propaguoti sovietinių idejjų, daugiau arba mažiau teko tai daryti. Toks prisitaikymas prie situacijos, matyt, priklausė nuo paties žmogaus charakterio ir būdo bruožų.

Šiandien dirbantiems bibliotekininkams papildomų darbų taip pat yra, bet ju pobūdis kitoks ir papildoma veikla yra daugiau ne primesta, o tiesiog išplaukianti iš kasdienybès aktualijų. Šiuolaikinė biblioteka orientuojasi ị daug îvairių sričiuc - kultūrinę, edukacinę, informacinę, socialinę ir kitas, o bibliotekos darbuotojas turi pasižymèti įvairiapusiais gebejimais bei kompetencijomis: jis turi būti lankstus, aktyvus, kūrybiškas, nuolat besimokantis pats ir mokantis kitus. Iš pateikèjų pasakojimų galima suprasti, kad šiandien bibliotekininkas dirba ne tik bibliotekinị, bet ir visuomeninị darbą, o papildomi darbai tarsi patys savaime atsiranda: bendradarbiaujant su kaimo bendruomene, rašant projektus ar užsiimant kita veikla.

Ne viena bibliotekininkė pasakojo apie tai, kad savo darbe tenka atliepti i̇vairiapusius bendruomenès poreikius, taip prisidedant prie įvairių visuomenès socialinių problemų sprendimo. Moterims tenka atlikti įvairius socialinio darbuotojo vaidmenis - pasakodamos apie šias papildomas veiklas jos vartoja tokius terminus, kaip „,socialinès funkcijos, socialinis centras, socialinis darbas“. Pateikejja Zita taip pasakojo apie rūpinimąsi skaitytojais: „Biblioteka ir seniau, ir dabar atlieka tokią ir socialinę funkciją. Ypač seniau būdavo, kai prisičiužinejję vaikai šlapiom kojom ateidavo ir kai dar Kęstučio aikštèj būdavom, buvo krosnis, ir, būdavo, pasisodini, batus nuauni, sniegą išpurtai iš batų ir pasodini vaiką prie krosnies kojom atkištom, kad padžiovintų prieš eidamas namo. Buvo ir taip... Ir dabar yra tokių, ypač kaimuose, bibliotekèlių, kuriom reikia ir arbatos puodeli pasiūlyt, ir sumuštini ar sausainị, ar dar ką nors. Neišnyko tas ir dabar, tokia yra mūsų buitis“ (VDU ER 2663/22, 119). Moterys šį darbą atlieka iš esmès savanoriškai, tai daryti nėra liepta jokių aukštesnių instancijų. Vienos tarsi apgailestauja, kad reikia tuo užsiimti, kitos išryškina tos veiklos svarbą ir savo reikšmingumą - jei ne jos, socialinių problemų padaugètų.

\section{Darbo sąlygos ir sunkumai}

Psichologiniu požiūriu darbas yra vienas reikšmingiausių asmens tapatumo šaltinių, o profesinè veikla yra labai susijusi su teigiamomis ir neigiamomis asmenybės emocinėmis būsenomis (Kavaliauskienè 2007). 
Todèl ir nagrinejjamuose naratyvuose atsiskleidžia bibliotekininkų emocijos ir savęs suvokimas darbo kontekste.

Ne viena buvusi bibliotekininke pasakojo šiandien sapnuojanti darbą bibliotekoje. Šiuos sapnus tiesiogiai galima susieti su emocijomis ir jausmais, kuriuos pateikejjos jaučia, kai prisimena laiką, praleistą bibliotekoje. Jei yra gailimasi, kad buvo palikta ši darbo vieta, sapnas gali vis grąžinti i bibliotekos erdvę, tarsi užbaigti paliktus darbus, ir atvirkščiai - jei bibliotekoje buvo nesmagu, nemiela - sapnas vis kartojasi tai primindamas.

Labai emocionaliai apie savo darbą bibliotekoje pasakoja pateikejja Valerija. Tačiau, skirtingai nei daugumos kitų pateikejjų, šios moters prisiminimai, ypač apie darbo pradžią, slogūs ir prisiminimų sužadinti jausmai - negatyvūs: „Aš prisimenu senose tokiose patalpose... Ir aš sapnuoju vis bibliotekos darbą, aš nežinau, kodèl man taip įsirěžè kaip nẻ vienas kitas toks darbas. Labai maža biblioteka, dar ir dabar sapnuoju tuos vaizdus, nu tokia mažyte buvo, kad Dieve Dieve... Lentynos... Dabar jau yra renovuotas tas namas, dabar yra ambulatorija ten. Ten ir bibliotekininkui buvo kambariukas duotas. Nu kas tas bibliotekininkas - nieks... Kaime tuo metu - nieks..." (VDU ER 2663/11, 59). Sapnuose regima biblioteka, apibūdinama kaip mažytė patalpa, galbūt yra paralelè su, pateikejjos manymu, tokiu pat „mažu“ - nereikšmingu ir nesvarbiu - bibliotekininku kaime. Folkloristė Vita Ivanauskaitė-Šeibutienė, tyrinėjusi sapnų naratyvus, yra pažymėjusi, kad savo sapną žmogus pajègus suprasti tiek, kiek yra raštingas skaityti jo kalbą pats arba kiek jam padeda daugiau už ji šioje srityje išprusęs „,vertejjas“ (Ivanauskaitė-Šeibutienè 2014, 54). Ir nors pateikejja teigia nežinanti, kodèl vis sapnuoja darbą bibliotekoje, vẻlesniuose jos naratyvuose išryškejja, kad dirbdama bibliotekoje ji jautėsi niekam nereikalinga, tai nebuvo jai mielas darbas, kuri laiką padirbusi ieškojo kažko kito.

Bibliotekoje, kaip ir kiekviename darbe, susiduriama su sunkumais. Paprašyti įvardyti sunkumus, su kuriais susiduria, buvę ir esami bibliotekininkai vardijo skirtingus dalykus. Vyresnieji daugiausia pasakojo apie sunkumus, susijusius su pačiu darbu: bibliotekinio darbo specifiką, fizinius sunkumus, kada reikejjo kraustytis su knygomis, apie neigiamą kaimo žmonių požiūrị, valdžios kritiką.

Vyresniesiems bibliotekininkams nepatiko neigiamas valdžios ir kaimo gyventojų požiūris ị juos, nes kiekvienas dirbantis žmogus nori būti suprastas ir palaikomas. Valdžios, skaitytojų, bendruomenès ar kitų visuo- 
menès grupių įvertinimas kiekvienam darbuotojui yra labai svarbus, nes teigiamai vertinamas savo profesinèje srityje žmogus jaučia ir asmenini pasitenkinimą, stengiasi dirbti geriau, pasitiki savo jẻgomis, jaučiasi gerbiamas (Day et al., 2006).

Esami bibliotekininkai vardijo kitokius sunkumus, kuriuos galima suskirstyti į materialinius bei moralinius. Beveik visos pateikèjos, kalbėdamos apie darbą, minèjo sunkias materialines sąlygas: nešildomas patalpas, mažas erdves, tai, kad daug rūpesčių ir bẻdų guldavo ant jų vienų pečių, retai buvo galima sulaukti pagalbos. Šiuose pasakojimuose dažnai jaučiamos nuoskaudos, kad niekam nerūpèjo nei biblioteka, nei bibliotekininkas, viskuo reikèjo pasirūpinti pačiai. Taigi, nors tuo metu Lietuvos valstybẻ jau buvo nepriklausoma, dažnu atveju nebuvo pasirūpinama kultūros žmonėmis.

Taip pat pateikejos pasakojo ir apie psichologinius sunkumus, susijusius su viešu kalbėjimu, renginių organizavimu, vienišumo jausmu, noru ịtikti skaitytojams, papildomais darbais, užkraunamais bibliotekininkui, ir pan. Natūralu, kad pasirinkę profesiją žmonès tikisi, kad gaus ,visą paketą“ žinių, kompetencijų ir ịgūdžių, kurie leis jiems iškart tapti specialistais. Vis dèlto dažnu atveju yra labai svarbus ir kontekstas, kur ir kokiomis sąlygomis tenka dirbti. Tuomet prireikia iš naujo mokytis pritapti ir įsitvirtinti toje aplinkoje, apmąstyti praeitị ir dabartinę patirtį (Beattie 2000). Šiuos psichologinius sunkumus būtų galima ịvardyti kaip subjektyvius, priklausančius nuo pateikèju prigimties bei būdo savybių.

I švados

1. Dauguma prisiminimais pasidalijusių pateikejjų apie savo darbą pasakojo teigiamai, gyvenimo laikotarpis, praleistas bibliotekoje, buvo įvardijamas kaip gražus ir vertingas. Buvę bibliotekininkai kalbejjo emocionaliau, buvo atviresni, daugiau pasakojo ne tik apie darbą, bet ir apie asmenini gyvenimą, nevengé pasakoti ir apie skaudžias gyvenimiškas patirtis. Kadangi dauguma pateikejjų yra moterys, be profesinės informacijos, matomas gana ryškus emocinis santykis su pasakojimuose atskleidžiamais įvykiais.

2. Pateikejjai savo vaikystès biblioteką ir bibliotekininką vertina arba teigiamai, arba neigiamai - daugiausia tai priklauso nuo bibliotekos darbuotojo elgesio ir požiūrio į vaiką. Buvusių bibliotekininkų menkai išsilavinę tèvai ir seneliai ị knygas ir skaitymą žvelgẻ gana 
skeptiškai, dažnas jų nemokejo skaityti, o esamų bibliotekininkų pasakojimuose matomas teigiamas tėvų požiūris į knygas, namuose atsiranda bibliotekèlès, biblioteka tampa ir vaikų žaidimų tema.

3. Vyresnieji bibliotekininkai, kalbėdami apie darbo pradžią, labiausiai akcentuoja neigiamą valdžios ir kaimo bendruomenés požiūrị i jauną specialistą, o šiandieniniai pasakojo apie tuometinę jų psichologinę būseną, kuri daugiausia buvo susijusi su pačiu pateikejjų asmeninėmis savybėmis. Ne vienam buvusiam bibliotekininkui dèl sudètingu gyvenimo sąlygu teko anksti eiti dirbti, kad galètų išgyventi, dabartiniai bibliotekininkai tokių trauminių patirčių turèjo mažiau, dauguma dirbti pradejjo tik baigę mokslus.

4. Bibliotekininkų pasakojimuose dažniau akcentuojamos dvi skaitytoju grupès: vaikai ir visuomenès atstumti asmenys. Vyresnieji pateikejai apie skaitytojus vaikus pasakojo kaip apie itin smalsius, mylinčius knygą, šiandienos bibliotekininkų pasakojimuose vaikai - priklausomi nuo technologijų, nebenorintys skaityti, kad pavyktų juos sudominti, reikia ieškoti išskirtinių būdų ir veiklų. Dar viena grupe skaitytojų, apie kuriuos pasakojo dabartiniai, bet kurių nėra vyresniųjų bibliotekininkų pasakojimuose - socialiniame užribyje gyvenantys asmenys.

5. Pasakodami apie renginių organizavimą, ir buvę, ir esami bibliotekininkai išskyrẻ bendradarbiavimo su kaimo bendruomene svarbą. Kalbėdami apie sunkumus, buvę bibliotekininkai daugiausia pasakojo apie kraustymąsi su knygomis ir neigiamą žmonių bei valdžios požiūrị, o šiandieniniai bibliotekininkai vardijo sunkias materialines sąlygas, vienišumo jausmą, pagalbos nebuvimą.

\section{Literatūra}

Akinsanya, Bach 2014 - Adedamola Akinsanya, Christian Bach. Narrative analysis: The Personal Experience Narrative approach. ASEE 2014 Zone I Conference, April 3-5, University of Bridgeport, Bridgpeort, CT, USA, 1-6. Prieiga internetu: http://www. asee.org/documents/zones/zone1/2014/Student/PDFs/21.pdf [žiūrėta 201804 08].

Astikienè 2017 - Sigita Astikienè. Bibliotekininkų pasakojimuose - praeities gyvenimo atspindžiai. Tarp knygu, nr. 3, 24-27.

Beattie 2000 - Mary Beattie. Narratives of Professional Learning: Becoming a Teacher and Learning to Teach. Journal of Educational Enquiry, vol. 1, no. 2, 1-23. Prieiga internetu: https://www.ojs.unisa.edu.au/index.php/EDEQ/article/viewFile/573/443 [žiūrèta $20180405]$. 
Būgienè 2011 - Lina Būgienè. „Aš jau prisimenu...“ Autobiografiniai lietuvių moterų pasakojimai folkloristo akimis. Tautosakos darbai, t. 41, 44-62.

Būgienė 2012 - Lina Būgienè. Istorijos patirtis ir refleksija Valkininkų krašto žmonių pasakojimuose. Tautosakos darbai, t. 44, 121-136.

Būgienè 2008 - Lina Būgienè. Objekto problema šiandienos tautosakos moksle ir naratyvų analizès perspektyvos. Tautosakos darbai, t. 35, 38-51.

Čepaitienè 2013 - Auksuolè Čepaitienè. Gyvenimo etnografija: vietos, struktūros ir laikas. Vilnius.

Day, Kington, Stobart 2006 - Christopher Day, Alison Kington, Gordon Stobart. The personal and Professional selves of teachers: stable and unstable identities. British Educational Research Journal, vol. 32, no. 4, 601-616. Prieiga internetu: https://onlinelibrary. wiley.com/doi/pdf/10.1080/01411920600775316 [žiūrèta 201804 08].

Daugirdaite 2006 - Vilma Daugirdaitè. Folklorinès patirties apraiškos gyvenimo pasakojimuose. Tautosakos darbai, t. 32, 214-224.

Ivanauskaitė-Šeibutienè 2014 - Vita Ivanauskaitè-Šeibutienė. Folklorinè sapno kalba: oneiriniai naratyvai bendruomeninèje komunikacijoje. Tautosakos darbai, t. 46, 53-71.

Kaivola-Bregenhøj 2005 - Annikki Kaivola-Bregenhøj. Pasakojimas ir pasakojimo pateikimas (ištrauka). Tautosakos darbai, t. 22 (29), 203-218.

Kraniauskienè 2004 - Sigita Kraniauskienè. Identiteto tyrimo metmenys: kartų identiteto paieška XX a. lietuvių autobiografijose. Sociologija. Mintis ir veiksmas, nr. 3-4, 40-52.

Kraniauskienė 2002 - Sigita Kraniauskienè. Socializacijos modeliai lietuvių autobiografijose: lyties ir laiko aspektas. Sociologija. Mintis ir veiksmas, nr. 1 (9), 66-74.

Leliūgienè, Sadauskas 2011 - Irena Leliūgienė, Justinas Sadauskas. Bendruomenès sampratos traktuotès ir tipologija. Socialiniu mokslu studijos, nr. 3 (4), 1281-1279.

Maniukaitė 2007 - Gražina Maniukaitè. Visuomenès silpnieji ir atstumtieji: vertybių konflikto ypatumai Lietuvoje. Filosofija. Sociologija, nr. 2, 45-54.

Moyer 1993 - Judith Moyer. Step-by-Step Guide to Oral History. Prieiga internetu: http:// dohistory.org/on_your_own/toolkit/oralHistory.html\#INTRO [žiūrèta 201806 08].

Petružienè, Gabalytė 2011 - Sada Petružienè, Renata Gabalytè. Vaikų skaitymo skatinimas: viešųiu bibliotekų veiklos aspektas. Tiltai, nr. 3, 237-251.

Stonkuvienè 2013 - Irena Stonkuvienè. Augti Lietuvoje: ugdymo kaip inkultūracijos eskizai. Vilnius.

Stundžienè 2012 - Bronè Stundžienè. Šiuolaikinė lietuvių folkloristika ir jos metodologiniai horizontai. In: Homo narrans: folklorine atmintis iš arti, 13-39.

Račiūnaitė-Paužuolienè 2011 - Rasa Račiūnaitė-Paužuolienè. Šiuolaikinių gyvenimo istorijų bei asmeninès patirties pasakojimų analizės ypatumai. Lituanistika, nr. 2 (84), 188-197.

Repšienė 2009 - Rita Repšienè. Mitologija šiandien: nacionalumo klausimai ir istorinès perspektyvos. Kultūrologija, t. 17, 30-45.

Tereškinas 2014 - Artūras Tereškinas. Permąstant socialinę atskirtị ir socialinį kentėjimą. Kultūra ir visuomenè, nr. 5 (3), 153-169.

Varnienè-Janssen, Račkauskaitė 2015 - Regina Varnienė-Janssen, Neringa Račkauskaitè. Naujos platformos lietuvių literatūros kūrinių sklaidai ir skaitymo skatinimui: problemos analizè. Informacijos mokslai, nr. 72, 74-101.

Vyšniauskaitė, Kalnius, Paukštytė-Šaknienė 2008 - Angelė Vyšniauskaitė, Petras Kalnius, Rasa Paukštytė-Šaknienè. Lietuviu šeima ir papročiai. Vilnius. 
Sigita Astikienè

“THIS IS NOT A JOB, BUT A DREAM...": THE PECULIARITIES OF THE LIFE NARRATIVES TOLD BY LIBRARIANS

Summary

The object of this article is life narratives of librarians, associated with their profession, recorded in the city of Ukmerge and its district. The aim of the article is to analyse these narratives, to reveal their specific features and peculiarities of the content. Material for this research was collected in 2016-2018. There were 30 life narratives collected and transcribed of the librarians aged between 32-91 years old. A semi-structured interview and observation were used while collecting the material and the descriptive, comparative and interpretive methods were used while analysing the content.

The article discusses librarians' recollections about reading and the library during childhood and youth, the beginning of work, interaction with people, working conditions and difficulties. Previous librarians were speaking more emotionally, they were more open, spoke not only about work, but also abot their personal life, they did not avoid to speak about terrible losses or a hard fate. Narratives of older respondents reflect difficult experiences of post-war period, which had an influence on their loved ones' perspective towards books, an early beginning to work and a late studying period. In the narratives of current librarians a positive point of view from the parents is noticed. Small libraries start to appear at homes and library is becoming a topic for children's games. Narratives of today's librarians reveal everyday-life differences of urban and rural librarians, the role of a library as a "shelter" for the community groups that are considered outcasts becomes apparent, and the supplementary social roles of a librarian are revealed.

When speaking about the beginning of work, the librarians mention materialistic and moral difficulties. More distinct difficulties are noticed between the narratives of urban and rural librarians. Respondents who started to work in rural libraries were looking for a connection with locals, 
wanted to be "taken care of" and offered help to while adapting in a community.

There were two distinct groups revealed in this article: children and persons rejected by the community. Older respondents were speaking about the children as especially knowledge-seeking, and loving books. Children in the narratives of today's librarians are addicted to technology, not wanting to read anymore, and exceptional ways and activities needs to be found to make them interested. Another group of readers, which are mentioned by the current librarians, but which are absent in the narratives by older librarians are persons living on a social border.

For the previous librarians various supplementary jobs were threw in by the government. Today's librarian is like a volunteer, having a lot of supplementary activities which provides a personal satisfaction as well. When speaking about organizing events, both, previous and current librarians singled out the importance of interacting with the rural community. When speaking about difficulties, previous librarians spoke mostly about moving out with books and the negative attitudes of people and the government, but current librarians named out difficult materialistic conditions, the feeling of loneliness, lack of support. 